\title{
“Or so the government would have you believe”: uses of "you” in Guardian editorials
}

\section{Ruth Breeze, Instituto Cultura y Sociedad, University of Navarra}

\begin{abstract}
Although second person pronouns are relatively unusual in formal written genres, they are frequent in the editorials of some newspapers. This has been associated with ongoing trends towards a more informal style of public discourse, and with the construction of more equal relationships between writers and readers, which may be either ideologically or economically motivated. This analysis of all the instances of “you” in Guardian editorials for 2011 brings to light several different ways in which the writer employs the second person. Although the primary motivation appears to be epideictic, in that the writer seeks to forge strong bonds with the readership and thereby strengthen the sense of communion and shared values, some other uses are identified, including dramatisation and irony. This leads on to consideration of the type of reader constructed by these uses of "you”, and the relationships projected between writer/newspaper, reader, and other entities.
\end{abstract}

\section{Keywords}


Discourse analysis, media language, editorials, personal pronouns, dialogicality, epideictics.

\section{Introduction}

The use of second person pronouns in written text is an area of particular interest for applied linguists and discourse analysts, since it can serve as an index to the dialogicality of a text or discourse, and shed light on the relationship that writers hope to build with their target readers. By using the first person "I" or "we" and the second person "you”, writers effectively construct the two main participants in the discursive interaction. As personal pronouns often offer "projected roles" which function as the textual personae of the intended writer and reader, it is clear that the pronoun system offers a powerful mechanism for persuasion, since through its careful use, potential readers can be coaxed to "converge" with the textual personae offered to them and to align themselves with the value positions open to them (Thompson and Thetela, 1995:108). One genre that is particularly interesting in this respect is the newspaper editorial. Not only do editorials often contain a high incidence of "we”, which might be expected since they embody the newspaper's considered, “official”, opinion on issues of 
topical interest, but in some cases they have also been found to make frequent use of second person pronouns (Westin, 2002; Steen 2003).

The presence of large numbers of second person pronouns in editorials is in itself worthy of some discussion, since "you" is relatively rare elsewhere in formal writing, and tends to be associated with spoken language and informal register (Biber, 1988, Biber et al., 1999, Hyland and Tse, 2004). In academic writing, “you” is extremely unusual in the sciences, but occurs at low frequencies in some social science and humanities disciplines (Hyland, 2004). Regarding media texts, some authors maintain that newspapers rarely address their readers directly, either in the second-person "you”, or through other reader-addressed speech acts (apart from straightforward assertions), except in the case of specific campaigns to muster support among readers for a particular good cause (van Dijk, 1988: 74; Birks, 2010: 58). However, this generalisation appears to hold more for news than for opinion genres. Biber (2004) describes an increase over the last 50 years in the use of first and second person pronouns in the print media as one of the ongoing changes to newspaper language. Moreover, this development does not appear to be confined to the English-language media. For example, according to Vis (2011), the use of second person pronouns rose sharply in Dutch newspapers in the second half of the $20^{\text {th }}$ century, an increase which was more marked in opinion than in other genres. 
On the other hand, although there is evidently a persistent underlying trend towards using less formal language in the media which may influence pronoun use, the effects of this are not palpable to the same degree in all newspapers, or particularly, in all editorials. Although Steen (2003) found an increase from 1950 to 2000 in the use of first and second person pronouns in editorials published in The Times, Westin (2002) found that the use of second person pronouns remained stable over the twentieth century in English broadsheet editorials. Moreover, her results also suggest that the presence of what she defines as "involvement features”, including second person pronouns, was consistently greater across the whole time period in the Guardian than in the other two newspapers that formed part of her corpus (The Times and Daily Telegraph) (Westin and Geisler, 2002).

The picture is thus somewhat complex, and in order to explore it further, we must bear in mind that various different factors may play a role in determining the number and type of pronouns used. Without a detailed study of the uses of "you” in particular genres, we will be at risk of overgeneralising, and perhaps even ignoring some important aspects of the use of the second person. The present study aims to address this issue by analysing the uses of the pronoun "you” in a corpus consisting of all the editorials published in the Guardian newspaper during 2011. 


\section{Texts and method}

The corpus for this study consists of around 600,000 words, comprising all the editorials from the Internet version of the Guardian newspaper published in 2011. The online Guardian publishes two or three editorials every day (mean 2.8), including the editorials published by its sister newspaper, the Observer, published on Sundays. The third editorial, when present, was usually a shorter, lighter piece, often headed "In praise of...” or “Unthinkable?”. The corpus was compiled manually and uploaded to SketchEngine. A brief quantitative analysis showed that “you” occurs 504 times (839.3 per million) in this corpus, as compared to “we” (1,279 per million), “I” (203 per million) and the impersonal pronoun "one” (161.5 per million). The SketchEngine Concordance function was then used to identify all the instances of "you”, and the concordance lines containing “you” were then analysed manually in order to determine their meaning and pragmatic function. In some cases, this required the researcher to return to the original text, but in most cases, it was possible to determine enough information about the meaning and function of "you" from the immediate context provided in the concordance lines. Once each example had been identified and described, a taxonomy was drawn up and the different uses of "you” were mapped out, 
along with representative examples. In what follows, the main uses of "you" in these texts are described and discussed in the light of the relevant bibliography.

\section{Discourse analysis}

In what follows, the ways in which "you" is employed in this corpus are analysed under various category headings. It is inevitable that some of these categories overlap, and that features of more than one use of "you” may be present in any given case. For the purposes of analysis, the instances of "you" were first divided into those that were perceived to be principally non-dialogic (for example, those which could easily be substituted by “one”, or were part of a set phrase), those that were clearly intended to involve the reader (that is, in combination with imperatives, or to project voices in a debate), and those cases in which "you” addressed a third party. The relative frequency of these three broad categories were as follows: 101 instances (20\%) were interpreted as being intrinsically non-dialogic in that they belonged to set phrases or were quoted as part of direct speech, while a further 104 instances (20.6\%) seemed to be examples of a general or impersonal "you" (although it could be objected that the choice of "you" rather than "we”, “one” or "people” might be thought to raise the dialogic tone); 220 instances (43.7\%) were perceived to invoke a relationship with the reader, and were 
thus dialogic in one of the senses described below; and 79 (15.7\%) were used to address another person or entity, of which 44 (8.7\%) belonged to one editorial which consisted of a set of questions aimed at Rebekah Brooks and James Murdoch in the wake of the News of the World telephone hacking scandals, and 35 (6.9\%) were directed towards other public figures.

It should be noted that the various roles of "you" identified in the editorials seemed to cut across the different types of editorial. Although the third editorial could be perceived to address the reader directly slightly more often than the heavier editorials, including rather more instances of the kind described in 3.2.1 and 3.2.2 below, the weightier editorials also made similar uses of the second person on occasion. On the other hand, the type of direct address explained in 3.2.6 was more frequently encountered in the heavier editorials. In general, however, major differences in authorial tone between the first two editorials and the third were rare, except in the case of the few purely humorous texts.

\subsection{Non-dialogic “you”}

\subsubsection{Non-interactive "you": formulaic expressions and direct speech}


Before analysing the various dialogic uses of "you" in the editorials, it is first necessary to explain that not all the instances of "you” in the corpus actually represented a potential dialogic use. Those which most clearly did not were the uses of you in wellknown expressions, in which "you" is obligatory as an integral part of the expression:

But before sinking into a psychological slump to match the economic depression, recall that money can't buy you love - or much else that makes life worth living. (Guardian, 1 December 2011)

\begin{abstract}
Along similar lines, there are also direct quotations from people in the news, or from famous figures. Most of these are like the two that follow, which function as part of the argument that the editorial writer is developing, and serve either to reinforce or demolish an argument.
\end{abstract}

“You're either with us or against us,” so said George W Bush.

Bismarck likened laws to sausages, saying you would do well not to watch either being made. 
A second category of examples where "you" seemed to be incidental - that is, its presence is a consequence of the writer's decision to quote direct speech, rather than an intention to address the reader - was that in which "you" is used in direct speech by some personal or impersonal entity, which is quoted directly in the text. In the example below, the writer reports what the Syrian protesters were saying, drawing on current events in the news by inserting the type of direct speech that is much more characteristic of news reports.

"From alleyway to alleyway, from house to house, we want to overthrow you, Bashar”, mourners chanted at one funeral.

Such insertions play a role in the editorial writer's argument, in this case illustrating the writer’s assertion that "Chants for reform gave way to chants for regime change” and building up the writer's contention that unrest is escalating in Syria. Such insertions could be said to be dialogic in the broad sense, in that the writer is alluding to shared knowledge of current affairs, and using it to build an argument. Nonetheless, although it might be argued that such examples have a certain dialogic potential when used as part of a longer text, they will not be analysed in greater depth here, on the grounds that the “you” here did not result primarily from the writer’s rhetorical choice. 


\subsubsection{Impersonal “you”}

The impersonal uses of “you” have been extensively documented by grammarians (Biber et al., 1999). In some examples found in this corpus, “you” is clearly used as a kind of impersonal pronoun meaning something similar to "one” or "people”. As such, it neither interpellates readers nor seeks to dialogue with them:

The high gritstone Dark Peak countryside remains a true wilderness, even though on a mist-free day you can see the fringes of Manchester and Sheffield from its tops.

Classically, the "you” meaning "people in general" is used to express universal truths or truisms, as a less formal alternative to the rather old-fashioned pronoun "one”. This impersonal "you” is typically applied to express hypothetical cases, and may be used to avoid two linguistic features that are felt to be detrimental to style: the stilted use of "one", on the one hand, and the passive voice, on the other. 
But the IFS found that if you give a pensioner a $£ 100$ fuel payment, they will spend well over a third on keeping warm, as against a mere 30th if the cash was not labelled this way.

On the other hand, in some instances in which "you" could be replaced by "one” or "us" or "people”, it seems pertinent to ask whether the choice of "you” has a particular ideological motivation. Consider the following example:

If there were ever a Conservative to convince you that there was substance to the Cameronian remaking of the Conservatives, it would be Michael Gove. Charming, urbane and brimming with concern about the chances of poorer children,

In this case, the choice of "you" rather than "us" is difficult to interpret, but may respond to a distancing strategy - the writer prefers to avoid "us", in the same way that he/she chooses to use more remote tenses ("was", "would be”), in order to raise the whole idea onto a more hypothetical plane. The writer has no wish to indicate that he/she is really convinced by Gove, which would be a possible consequence of using "us". This use of "you” appears to be close to that which is often described as general and impersonal, by which the author "assimilates himself to a much wider class of people” (Kitagawa and Lehrer, 1990). In effect, in this type of example, “you” means 
"everyone”. The only differences between saying "you” and saying "we” or "people” in this type of example are related to the desired level of informality/orality, the extent to which the writer might want to be included in the generalisation, and the extent to which the writer wishes to project a direct relationship with the reader. We might conclude that although these uses of "you" are impersonal, they are not as impersonal as the alternatives "one" and "people" might be, and they differ slightly from "we" in the extent to which they potentially exclude the writer. On the other hand, it would be difficult to maintain that they invoke a high degree of dialogicality, and in this they clearly differ from the examples discussed in section 3.2 below.

\subsection{Involving the reader}

\subsubsection{Connecting with readers' lives}

"You" often appears to be used to connect with readers by referring to everyday situations that could really be part of their lives. This desire to connect with readers' lives and habits could be interpreted as a general attention-grabbing strategy, but also, and perhaps more importantly, as an expression of the general desire to project an empathetic relationship, a community of readers bonded by shared values, feelings and 
experiences. The celebration and reinforcement of shared values is understood to be typical in epideictic genres (Perelman and Olbrechts-Tyteca, 1969), and the epideictic aspect of newspaper discourse in general, and editorials in particular, has been noted by some previous analysts (Sullivan 1993; Sheard, 1996; López Pan, 2014). The following example offers a shared experience expressed in the second person with which readers are quite likely to identify.

It's a story familiar to everyone who uses public transport. You wait for ages, the fare keeps going up and then the journey is cut short before you even arrive.

The "you" of this kind projects a role for the reader in which the reader is assumed to be participating in the important public events of the day, sharing the ups and downs of British life in 2011:

Your perception of whether the Olympic ticket ballot was fair will probably depend on whether you ended up with front row seats or whether, like the mum of double Olympic champion Bradley Wiggins, you got nothing at all. 
Occasionally, examples of this type construct the reader as doing things that Guardian readers actually do in their capacity as Guardian readers, such as completing the Guardian crossword:

... his alphabetical crosswords, where you have to fill the answers into an unnumbered grid

Sometimes the reactions attributed to the reader are of a more concrete nature. In the next example, the writer places him/herself in the reader's house to predict what the reader is doing.

Well done, Mr Murray; a thousand plaudits. If you, the reader, are reading this earlyish, you've probably got the telly on, wondering whether he can become the first British man to win a grand slam since the 1936 Fred Perry triumph.

Such applications are reminiscent of the "you" as "situational insertion” described by Kitagawa and Lerner (1990), in which the level of familiarity associated with the second person serves to involve the reader/listener in the story or argument. 
Finally, it is also worth noting that sometimes genuine clusters of "you"/"your"/"yours" appear, which would be normal in informal conversation, but which are highly unusual in writing:

Your home town is like your family. It may be dire or delightful. You may love it or hate it. But it is yours and, wherever you go, you can't escape it.

The strategy of addressing the reader directly, and attributing experiences, thoughts and feelings to him/her, builds a rhetorical effect of closeness and involvement. It is the antithesis of the authoritative tone that has traditionally been associated with the broadsheet editorial, and as such can be seen as indicative of a specially close relationship with readers, not so distant from the familiar voice observed by Conboy (2006) in tabloid newspapers.

\subsubsection{Building a bond between "you" and "us"}

On many occasions, in addition to addressing readers through “you”, the writer also constructs "you" in a way that is parallel to "I" or "we", as in the following two examples: 
An early environmentalist, Rolt did much to make enthusiasm for a gentler and slower world popular. And he proved that you and I, with a sufficient head of enthusiasm and steam, could even run a railway.

The last thing television needs is a gang of celebrity chefs telling us what to eat. But if you can forgive the focus on personality and listen to the message instead, then a series of programmes on Channel 4 this week is worth paying attention to.

In both cases, the writer projects a sense of solidarity with the reader: in the first, "you” and "I" are mentioned together to affirm positive capacities, while in the second, "us" and "you” are construed as sharing a distaste for celebrity chefs. In this instance, the bonding between writer and readers is discursively reinforced, as they consider a common enemy who is constructed as a threat to their lifestyle and, by implication, to their freedom.

\subsubsection{Adopting a colloquial voice}


As we have already noted, in combination with the strategies of direct address discussed above, the editorial writer often seems to adopt an informal tone. The conversational style adopted by the writer includes contractions, fragments, and colloquial vocabulary, as in the following example:

Time to get out of the house? Perhaps you'd like a couple of hours in the fresh air, watching football. If so, there's plenty of choice.

In some cases, the more conversational style is also deployed in the first or second editorial, on more serious topics, when it is used for ironic or humorous purposes:

Chief executive Ivan Glasenberg will sit at the top of this money mountain with a stake worth a cool \$9bn. And you thought bankers had it good.

There are a few instances in which the editorialist even enacts a kind of sustained conversation, in which the reader's response is assumed, though not stated.

After inventing several new swearwords, he'll be bolting a whirligig of an unanswerable ace about... now. He'll be making the grimace, the one that scares sharks about... now. Did he win? Oh, we'll tell you in a sec. But first, please, let's 
celebrate the fact he has matured from a truculent teen into a player of often unassailable prowess and, though he still doesn't suffer fools gladly.

As we shall see below, this kind of interaction with readers falls into various different patterns, and is often, though not always, informal and conversational in tone. When the conversational style predominates, it is clear that we are looking at instantiations of the increasing preference for informal language, as has been documented by Fairclough (1995) and Lehti (2013).

\subsubsection{Interacting with the reader}

Apart from - or in combination with - informality, the writer uses a variety of strategies to simulate interaction with the reader, including imperatives, warnings and rhetorical questions. One of the most typical combinations found here is "you" with one or more verbs in the imperative:

Click through the records of the 779 prisoners who have passed through the Guantánamo system, on the Guardian's interactive guide, and you find an unpredictable mix of the evil, the criminal and the accidental. 
In cases of this kind, the imperative creates a simulation of closeness, which is complemented by the use of direct address. In a few cases, the reader is being addressed in a very concrete way, because the writer is urging the reader to take a concrete action, and to respond to one of the newspaper’s campaigns (Birks, 2010).

So please help us in the hunt and nominate those you believe are making a positive practical difference and breaking new ground in the process.

However, the next example is more typical, in that it shows how this style of interactional direct address is particularly effective to make a political point. In these cases, no direct response to the newspaper is required - the interaction is carried out on the level of political dialogue.

Contrast this to the statements that David Cameron made in February and you get some measure of how this military campaign has gone, even in the eyes of those who launched it. 
Direct address also includes the use of warnings, such as the following caveat which attributes particular sentiments to the reader, before uttering a caution, in a dramatised exchange:

By all means clamour for MPs to consider privacy, but be careful what you wish for.

"You" also figures in the familiar context of rhetorical questions, which again simulate a kind of interaction between writer and reader:

Do you recall all the power of the tweet, as lauded only a fortnight ago?

Finally, "you" is sometimes invoked as a deictic pointing to a physical place. In the next example, "near you” is used ironically, exploiting a cliched phrase, to create an implicature that renders more explicit mention unnecessary.

The disaster movie's subtext is institutional failure in the face of adversity. Don't imagine it hasn’t all been considered by a government near you. 


\subsubsection{Involving readers in an unlikely or hypothetical situation}

Above we examined the use of “you” to connect with readers' everyday lives. However, it is often the case that "you" is used in contexts which readers are extremely unlikely to experience. We might argue that it is just possible that a reader might identify with the first of these examples:

If you are due for a heart bypass next week, you will have more than a passing interest in whether or not your hospital is trying to do things on the cheap.

However, if only a few readers are preparing for heart surgery, hardly any are going to swim the Channel:

Even with nutritional comforts unavailable to Webb - carbohydrate drinks and jelly babies, administered via long poles so swimmers don't breach the bar on physical contact - a special sort of madness is needed to take all this on. You can insulate yourself mid-sea by singing a familiar tune; you can emblazon "tomorrow" on your forearm to steel yourself for the struggle; but you must obey just one instruction: follow the boat. 
And equally few are going to be lost at sea off Cornwall and have to rely on the coastguard service:

Falmouth is there to coordinate a rescue, patch your call through to a doctor or simply call your mum to tell her you are still alive.

In these cases, the use of “you” seems to be intended to draw the reader's attention by writing him/her into the dramatic scenario being described. These second-person mininarratives coincide to some extent with what Kitagawa and Lehrer (1990) term the "lifedrama subtype" of uses of the second person, associated with the first move of anecdotes, which they illustrate with the story-opener: “you're in Egypt admiring the pyramids when suddenly you run into your next-door neighbour from home”. These authors point out that in conversation, the role of this "you" is generally limited to the "scene setting portion of a mini-tale" (1990: 749). In the editorials corpus, the "you" drama generally also appears at the beginning of the text, although there are some examples of "you" occurring in dramatisations elsewhere in the narrative.

\subsubsection{Staging a debate}


On a substantial number of occasions in this corpus, the "you" of the text is constructed as an imaginary debating partner with whom the editorialist is engaged in discussion. This is clearly exemplified by this example, in which “you” is employed as proffering the "argument" that is to be disputed:

You cannot beat cheap Chinese competition, runs the argument. Well, yes and no: German manufacturers also buy foreign parts - but their imported proportion of what is known in the jargon as intermediate purchases is much lower: around $25 \%$ versus about $50 \%$ in the UK.

It should not be supposed, necessarily, that the reader is meant to identify with that partner. However, the hypothetical sparring partner is brought closer to the reader through the use of "you”, and through the accompanying imperatives. In the following example, "you" is positioned as taking a line of logic that would lead to an absurd conclusion - "you” is not necessarily the reader, but is associated loosely with the reader and that reader's possible train of thought.

Follow that logic and you end up in the land of the absurd, with prime ministers taking credit for not abolishing the NHS. 
This deployment of "you” as an argument-bearing actor is clearly illustrated by the following example, in which "you” is positioned as having various different argumentative positions open to him/her. This not only suggests a kind of mental agility on the part of the writer, but it also flatters the reader by roping him/her into the game of testing out the different arguments.

He is the latest receptacle of the vote that is more right-wing than Mitt Romney, a man who worries about not being conservative enough. You can argue that this leaves the centre ground to Mr Obama. But you could equally well show that the centre ground of politics is moving inexorably rightwards.

On other occasions, the reader is definitely roped into the debate as a committed participant. In the next example, the reader is addressed through the verb of perception, and the combination with "if”, which opens a dialogic space for the reader's possible response, heightens the tone of direct address.

If that sounds unprogressive to you then you are in good company: both $\mathrm{Mr}$ Cameron and Nick Clegg described VAT as regressive before the election. 
Perhaps the most interesting formulae used in this context are those which construct the reader as a potential victim of someone's mendacity. The following examples serve to illustrate how the leader writer positions the reader as the target of political lies. These examples are complex, because the “you”-reader is framed as a possible victim of propaganda messages, and yet at the same time, the expression "have you believe" is associated primarily with contexts in which people definitely do not believe what they are being told. More than anything, these examples convey the sense that politicians are trying to deceive the readers, but the readers are unlikely to fall into the trap of believing their lies, particularly thanks to the editorial writer's efforts on their behalf.

Or so the government would have you believe.

So is the institute's forecast and the expected rise in joblessness more dire news for Britain caused by the euro crisis washing across France and now also lapping at our gates? That is what David Cameron and George Osborne want to have you believe.

In these cases, the writer and reader are aligned with "you”, in such a way that "you” could practically be replaced by “we”. The reason why "we” is not used probably lies in the writer's favoured dialogic style, and in his/her desire to assert his/her authority and 
expertise in order to debunk these political lies for the benefit of the reader. In other words, although the editorials favour a democratising, informal voice, they also assert the writer's superior understanding and interpretation of events, much as traditional editorials do.

One interesting aspect of the kind of written debate described in the previous section is the way in which thoughts, feelings or perceptions are attributed to the reader. This approach seems to be common with private verbs such as "think”, "believe”, “doubt”, "see”, “hear”, and so on.

You might have thought club class fees would now be a problem for students, not Whitehall.

Add in financial engineering to convert clinical savings into dividends, and you see why we are reporting today that some doctors will get very rich, very quick.

If you doubt it, look at this week's warning from the International Energy Agency. 
By staging this understanding of readers' thoughts, the writer builds a more varied, dialogic argument, which both engages possible reader reactions and preempts possible counter-arguments.

\subsection{Interacting with another "you"}

\subsubsection{Interacting with actors}

The use of "you" in these editorials also extends beyond projected writer-reader relations to more complex types of interaction involving other people, mainly protagonists in the events on which the writer is commenting. Three main patterns emerge: "you” to address a protagonist directly in a rhetorical fashion, with a critical, interrogatorial voice; “you” to address a protagonist in a more familiar way and, perhaps, thereby to involve the reader in this by putting him/her in that protagonist's shoes; and "you” to project a relationship between a particular figure and the reader.

When "you" is used to address a protagonist directly, the favoured form is the rhetorical question, which places the writer/reader in a position of (discursive) power as a questioner. Such examples are not uncommon in this corpus - as noted above, one 
editorial consists entirely of questions aimed at the protagonists of a major scandal. World leaders are also addressed in this way, as in the following example in which "we" embraces writer and readers, while “you” is clearly an interrogatory “you” addressing Putin.

How many more, Mr Putin? How long are we supposed to mourn fellow journalists who died trying to tell us, and their fellow Russians, what a slack, slimy, savage state you run?

This type of "you” is thus an externalising "you” which creates distance between the writer/reader and the person under questioning. The type of simulated direct address in this example is also found when the writer stages an attack on a political leader in the form of a personal criticism:

But it's not what you're saying that's the problem, Mr Cameron. It's what your government's doing.

However, it is hard to sustain such direct address for long, and most of these examples are just dialogic insertions in a longer criticism set out in the third person, as below, where there is a rapid re-focusing from direct address to third person argumentation. 
100 days in, Mr Miliband, you need a plan. It's time the Labour leader explained what he believes in.

Interestingly, there is often alternation between second and third person in these cases, where the discursive intention behind "you" seems to be to get the reader to see the protagonist's problem from the inside. The result is not exactly empathy, but an original take on a serious issue:

Putin needs more than just money. He needs rebranding. When you have put so much effort into presenting yours as the sole hand on the tiller, it is difficult to collectivise the leadership.

Of course, it's difficult to know which way to turn if you're Obama or Cameron. The third type of "you" used in connection with an external other is the addressee "you" exemplified in the following corpus extracts:

As Michael Gove could tell you, having Mr Balls as your opposite number is a job in itself. 
The feelbad factor is often deadly for politicians, as Gordon Brown could tell you.

In these cases, the leader writer positions the political figures as potentially conducting a dialogue with the reader, who is brought into the debate as "you”. We may note that the sentiments that these politicians are supposed to be able to communicate to us are not based on anything these people have actually said - the writer is in fact putting words into their mouths, and then presenting them as a message to the reader.

These interactions between writer, reader, protagonist and “you” are complex, but the main idea emerging from this section is that "you" generally points to an intention, on the part of the writer, to involve the reader more directly in the ongoing debates of social and political life, and to create a more dynamic style by simulating two-way and three-way interaction.

\subsubsection{Metadiscursive perspectives on "you"}


Occasionally the writer also picks up on the use of "you" by someone else, in order to comment on that person's discursive style. For example, in the first example provided below, the writer is commenting on Milliband's use of “you”.

The Labour leader addressed his speech to “you, the British people”, repeating time and time again that "you believe”, “you know” and “you remember”.

But just before this, the writer has subtly undermined Milliband's approach with the comment "It was both striking and touching that Mr Milliband believes that the public's values are Labour values.” The implication for the reader seems to be that Milliband's confident use of "you” is empty, or at least, misplaced.

\section{Constructing the reader}

The nature of the dialogue conducted with hypothetical readers in these editorials affords some insights into the writer's assumptions concerning those readers. These assumptions are of various kinds. First, it is unsurprising that the writer takes for granted certain aspects of the readers' political alignment. People who choose to read a particular newspaper generally identify with that newspaper's stance on social and 
political issues (Bell, 1991), and by playing to the audience in this way, the leader writer consolidates the bond with readers. In this sense, the editorial has an obvious epideictic function in celebrating shared orthodoxies and reinforcing the sense of community based on common values (Enos, 1990; Sullivan, 1991; López Pan, 2014). Examples such as the following show how the reader is roped into particular value stances concerning party politics, particularly on issues such as the environment or the Middle East.

As a swath of enraged ecologists, academics and NGOs has claimed, his party put in power on a promise to be the greenest ever elected - is now set to acquire the mantle of being the most environmentally destructive in recent history. You can see their point.

Nevertheless, these editorials also position themselves towards a plural readership, or at least one that admits the importance of pluralism and debate. It is noticeable that the writer often extends an invitation for the reader to disagree with what is being said, or to adopt a number of different opinions on the subject at hand. 
You can agree or disagree with those speeches - their approach was very different and each was controversial. Nevertheless, each was also based on a serious argument.

You can argue that this leaves the centre ground to Mr Obama. But you could equally well show that the centre ground of politics is moving inexorably rightwards.

By legitimising different possible stances, the writer constructs his/her own attitude as one of tolerance and openness. Interestingly, we could speculate that by projecting a tolerant and open attitude, the writer probably hopes to resonate all the more with the left-leaning, progressively-minded Guardian readership. Projection of a "liberal” or "tolerant" view is thus in itself a political move, and a move with potential epideictic implications.

Along similar lines, it is evident that the writer often builds a discursive relationship in which he/she aligns him/herself with the reader as a potential victim of the (Conservative) government in particular, and the political classes in general. Of course, although the reader is a victim, for example, of politicians’ lies, the reader is also intelligent enough to see through those lies. The example we have considered above is 
interesting in this respect, in that it constructs politicians as deceiving the public for political ends, while offering a writer-reader relationship of solidarity and mutual respect.

So is the institute's forecast and the expected rise in joblessness more dire news for Britain caused by the euro crisis washing across France and now also lapping at our gates? That is what David Cameron and George Osborne want to have you believe.

The use of irony and implicature also helps to build a sense of shared values (Perelman and Olbrects-Tyteca, 1969). Arguably, by building an indirect or understated criticism, the writer hopes to consolidate a sense of empathy with the Guardian's readership.

If you want to know why you should vote yes in May's electoral reform referendum, just listen to Dr John Reid's peroration for the noes yesterday.

The following example constructs the familiar right-wing anti-benefits discourse (held by “people”) as an insult to the intelligence (“extraordinary and exasperating”), held up against the yardstick of "you”, as someone who would never be tempted to stay in bed by such a paltry amount. 
It is both extraordinary and exasperating to learn that people imagine jobseeker's allowance - which pays $£ 67.50$ a week - as a king’s ransom that invites you to stay in bed.

Finally, we might also note that these editorials also position their readers variously as good citizens, hard-working people, and fundamentally middle-class. Let us consider the following examples which position "you" as a law-abiding citizen who observes misconduct in others, and as a sensible spender who observes profligacy in others

AA research suggests that many drivers are already curbing their speed; but what is striking, as you see every day on the motorways, is how many still aren't.

If you have ever witnessed customers walking into a store and instinctively reaching for the most expensive goods, then you can grasp what is going awry in university finance.

\section{Discussion}


The frequency of “you” in editorials has chiefly been interpreted by previous researchers as a product of the trend towards informalisation in discourse (Westin, 2002; Steen, 2003). However, the examples analysed here point to a more complex panorama, characterised by the presence of several different patterns of dialogicity that require further discussion.

First, perhaps most importantly, there is certainly evidence that addressing readers as "you" is symptomatic of an informal tone which constructs an apparently more equal relationship with readers than would be created through the use of first or third person pronouns. The choice of a conversational style in genres once thought to be formal or impersonal may well reflect changes in the underlying paradigm of public discourse. Previous researchers have discussed the wide-reaching phenomenon of "informalisation" in official or institutional discourses. This has been hailed as one of the core areas of discursive democratisation, in that it embodies "the reduction of overt markers of power asymmetry between people of unequal institutional power” (Fairclough, 1995: 98).

A second aspect of the Guardian's second person discourses is the evident attempt to bring both the language and the content closer to the reader's own life, to assume some degree of identification with the reader, to enter the reader's "habitus". This can be 
identified with the second phenomenon that Fairclough (1996: 7) identifies with the “engineering of informality”, namely, the increase in personalisation. In Fairclough's words, this is achieved through the construction of a "personal relationship" between the producers and receivers of discourse, which has a similar effect to “conversationalisation”, but extends further to make assumptions about readers’ lives and values. The writer stages a high degree of intimacy with the reader, blurring the boundaries between the public and the private sphere.

Attempts to evaluate the interconnected features of informality and personalisation in public discourse have proved inconclusive. By adopting a personal, conversational tone, the writer of a webpage, media text or official document is spreading the discursive practices of ordinary life into the public sphere and empowering those who might otherwise feel intimidated (Fairclough, 1996; Fairclough and Mauranen, 1997: 91). On the other hand, the full ideological potential of this change has yet to be explored, since the erosion of power differences in language certainly does not imply a corresponding elimination of power structures in society, and may even serve to make the workings of such structures less visible to the participants in the discourse. In journalism, the emergence of a distinctive, demotic "tabloid voice” has been amply documented (McLachlan and Golding, 2000; Conboy, 2006, 2007, 2010), and broadsheet newspapers have also been shown to have modified their language, style, format and 
even news values to bring them closer to the tabloids. While some commentators, such as McNair (2003), regard this as a positive development, since it leads to a style of journalism that is less pompous, less pedagogic while at the same time more human and more demotic, others have expressed reservations. In particular, we should not forget the underlying economic motivation: the informalisation of media voices may well be intended to "emphasize their congruence with popular culture with a view to maintaining circulation in an era of unprecedented competition” (Conboy, 2010: 113). In the case of Guardian editorials, however, although the voice is often colloquial and familiar, there seems to be little evidence of convergence with other salient features of tabloid discourse, such as celebrity culture or chauvinistic values. In Conboy's terms (2010: 114), if we are witnessing some degree of tabloidization here, then it is in a very minor key.

Aside from this issue, we have also observed that the familiarity assumed with the reader enables the writer to place "you" in a variety of situations ranging from the mundane to the dramatic. Here, "you” seems to serve a double purpose, bringing the reader closer to the writer, and also projecting him/her into the events or issues in question, in much the way that people use "you” to involve listeners when they tell anecdotes (Kitagawa and Lehrer, 1990). Again, strategies from informal conversation are being used, but this time the intent is to dramatise rather than to build community. 
Finally, we may also distinguish two specifically rhetorical uses of "you": the "you” employed to address public figures (such as Putin or Cameron), and the "you” used as a hypothetical debating partner in the staging of dialogue (Thompson and Thetela, 1995). In the entire corpus, no evidence was found of “you” being used to create a greater distance between the writer and the reader (Kim, 2009), or between the reader and some other entity (Baker et al., 2013).

The limitations of this study are evident, since it is based on an analysis of the editorials in one newspaper for only one year. Future qualitative research is required to understand diachronic developments in the different uses of “you”, and to examine the use of personal pronouns across the current landscape of newspaper editorials, opinion articles and media blogs.

\section{Funding acknowledgement}

This research was conducted within the project "Metadiscurso y lenguaje evaluativo: perspectivas teóricas y de análisis en el discurso periodístico”, supported by the Ministerio de Economía y Competitividad [FFI2012-36309].

\section{References}


Baker, P., Gabrielatos, C., McEnery, T., 2013. Sketching Muslims. A corpus-driven analysis of representations around the word "Muslim” in the British press 1998-2008. Applied Linguistics 34(3), 255-278.

Bell, A., 1991. The language of news media. Oxford, Blackwell.

Biber, D., 1988. Variation across speech and writing. Cambridge University Press, Cambridge.

Biber, D., 2004. Compressed noun-phrase structures in newspaper discourse, in: Aitchison, J., Lewis, D. (Eds.), New Media Language. Routledge, London, pp. 169181.

Biber, D., Johansson, S., Leech, G., Conrad, S. and Finegan, E., 1999. Longman Grammar of Written and Spoken English. Longman, London..

Birks, J. 2010. Press protest and publics: the agency of publics in newspaper campaigns. Discourse and Communication 4(1), 51-67. 
Chafe, W., 1985. Linguistic differences produced by differences between speaking and writing, in: Olson, D., Torrance, N., Hildyard, A. (Eds.) Literature, language and learning: the nature and consequences of reading and writing. Cambridge University Press, Cambridge, pp. 105-123.

Conboy, M., 2006. Tabloid Britain. Constructing a community through language. Sage, London.

Conboy, M., 2007. The language of the news. Routledge, London.

Conboy, M., 2010. The language of newspapers. Socio-historical perspectives.

Continuum, London.

Enos, T., 1990. ‘An eternal golden braid’ rhetor as audience, audience as rhetor, in:

Kirsch, G., Roen, D. H. (Eds.), A sense of audience in written communication. Sage, Newbury Park, pp. 99-114.

Fairclough, N., 1995, Critical discourse analysis. Routledge, London. 
Fairclough, N., 1996. Border Crossings: Discourse and Social Change in Contemporary Societies, in: Coleman, H., Cameron, L. (Eds.), Change and Language.Multilingual Matters, Clevedon, pp. 3-17.

Fairclough, N., Mauranen, A. 1997. The Conversationalisation of Political Discourse: A Comparative View. The Belgian Journal of Linguistics 11, 89-119.

Hyland, K., 2004. Disciplinary discourses: social interactions in academic writing. University of Michigan Press, Ann Arbor.

Hyland, K., Tse, P., 2004. Metadiscourse in academic writing: a reappraisal. Applied Linguistics 25(2), 156-177.

Kim, C., 2009. Personal pronouns in English and Korean texts. A corpus-based study in terms of textual interaction. Journal of Pragmatics 41, 2086-2099.

Kitagawa, C., Lehrer, A., 1990. Impersonal uses of personal pronouns. Journal of Pragmatics 14, 739-759. 
Kuo, C., 1999. The use of personal pronouns: role relationships in scientific journal articles. English for Specific Purposes 18(2), 121-138.

Lehti, L., 2013. Between public and private. Conversationalisation in French politicians’ blogs. Journal of Language and Politics 12(4), 508-536.

López Pan, F., 2014. On the newspaper as an epideictic meeting point. Argumentation. Epub ahead of print. DOI 10.1007/s10503-014-9337-z

McLachlan, S., Golding, P., 2000. Tabloidization in the British press: a quantative investigation into changes in British newspaper, in: Sparks, C., Tulloch, J. (Eds.) Tabloid Tales. Rowman and Littlefield, Oxford, pp. 75-90.

Perelman, C., Olbrechts-Tyteca, L., 1969. The new rhetoric: a treatise on argumentation. University of Notre Dame Press, Notre Dame, Indiana.

Sheard, C., 1996. The public value of epideictic rhetoric. College English 58, 765-94.

Steen, G., 2003. Conversationalization in discourse: stylistic changes in editorials of The Times between 1950 and 2000, in: Lagerwerf, L., Spooren, W., Degand, L. (Eds.), 
Determination of Information and Tenor in Texts: Multidisciplinary Approaches to Discourse.Nodus Publikationen, Münster, pp.115-124.

Sullivan, D. L., 1991. The epideictic rhetoric of science. Journal of Business and Technical Communication 5(3), 229-245.

Thompson, G., 2001. Interaction in academic writing. Learning to argue with the reader. Applied Linguistics 22(1), 58-78.

Thompson, G., Thetela, P., 1995. The sound of one hand clapping: The management of interaction in written discourse. Text 15(1), 103-127.

Westin, I., 2002. Language change in English newspaper editorials. Rodopi, Amsterdam.

Westin, I., Geisler, C., 2002. ICAME Journal 26, 133-152.

Van Dijk, T. A., 1988. News as Discourse. Lawrence Erlbaum, Hillsdale. 
Vis, K., 2011. Subjectivity in news discourse. A corpus linguistic analysis of informalization. PhD Thesis, Vrije Universitat Amsterdam http://dspace.ubvu.vu.nl/handle/1871/19775

\section{Editorials}

Guardian, 1 December 2011, Living with less: wellbeing in the slump. 